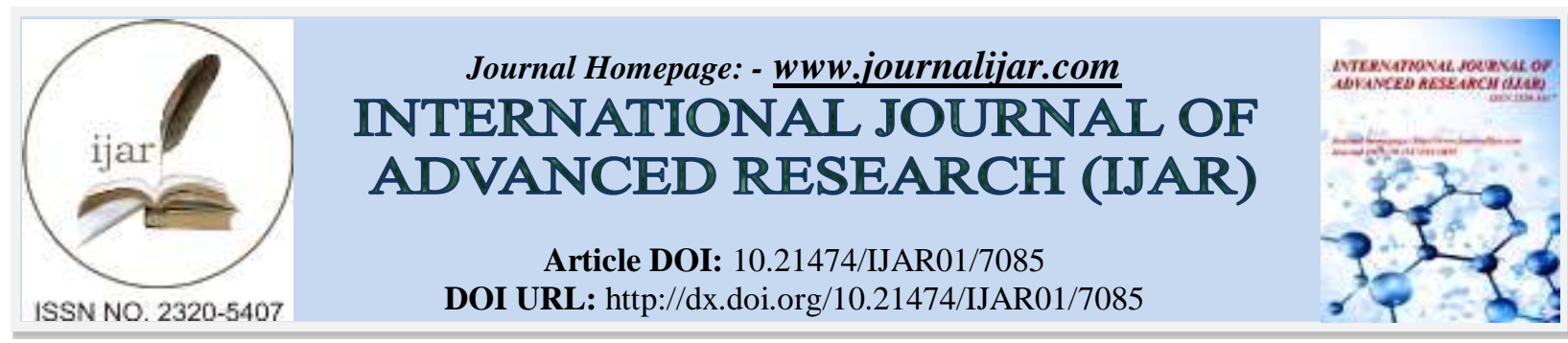

RESEARCH ARTICLE

\title{
PERSONNEL PERFORMENCE AND ORGANIZATIONAL COMMITMENT IN UNIVERSITY HOSPITALS FROM NORTHEASTERN MEXICO: A STRUCTURAL EQUATION MODELING.
}

M. A. Sonia Lozano-Quintanilla and Dra. Adriana Segovia-Romo.

Facultad de Contaduría Pública y Administración, Universidad Autónoma de Nuevo León, Av. Universidad S/N, Col. Ciudad Universitaria, San Nicolás de los Garza, Nuevo León, México.

\section{Manuscript Info}

Manuscript History

Received: 12 March 2018

Final Accepted: 14 April 2018

Published: May 2018

Keywords:-

personnel performance, organizational commitment, job satisfaction, university hospital, structural equation modeling.

\section{Abstract}

This research highlights the study of personnel performance and organizational commitment in university hospitals from northeastern Mexico. Professional health personnel plays an important role in the hospital environment and is an essential issue for the organizational results, as attention is given to the study of organizational factors and individual perceptions that influence organizational behavior such as job satisfaction. The investigation seeks to identify organizational factors that determine personnel performance and organizational commitment through professional health personnel behavioral features, using structural equation modeling based on partial least squares regressions. The analysis developed by the SmartPLS 3 software reveals interesting results that refute what previous research exhibit.

Copy Right, IJAR, 2018,. All rights reserved.

\section{Introduction:-}

Personnel performance is one of the main indicators of a company's results; likewise, organizational commitment benefits the stability of any organization. This research consists of the identification of the organizational factors and individual perceptions related to organizational climate, that determine personnel performance and organizational commitment through job satisfaction in university hospitals from northeastern Mexico.

The individual perspective that people bring to their workplace must be considered in every organization, where communication is used as the main dynamic (Griffin and Moorhead, 2010). Because of personal perspectives and characteristics, each individual affects the organization. In the same way, the climate, the processes, and the organizational factors affect people, to give place to individual perspectives.

It is important to highlight that human resources perceptions regarding the environment and working conditions in a hospital affect the service provided (Gonzalez-Garza, 2006). In other words, it affects the hospital results; regarding this statement, plentiful papers have studied personnel performance in relation to different other variables.

In another instance, organizational commitment is a field that is part of the behavior of organization members. Organizational commitment is related to the empathy that an employee maintains with the organization in which he works and the desire to continue belonging to it (Arias, 2006).

Meyer and Allen (1997) stated that commitment is a multidimensional concept and it is classified into three types: affective, normative and continuance. Affective commitment refers to the degree of affinity that an individual 
maintains with the organization for its own sake. Normative commitment is related to the affinity between an individual and his organization in which the individual believes that belonging to it, is an obligation. Continuance commitment is present when, for an individual, the termination of the relationship with the organization determines a great loss for himself.

On the previous basis, the degree of commitment depends on the elements of the organization in which the individual develops, on society, their conditions, and individual critical thinking. Due to the complexity of the factors inherent to the commitment, a psychological connection develops between the individual and his social environment, allowing the individual to adapt to the particularities of the environment (Meyer et al., 2006).

Therefore, organizational commitment is generated, in part, from the psychological well-being of personnel, directly affected by the degree of job satisfaction (Arias, 2006). Given the impact of the work environment on individual perceptions, job satisfaction is part of the study of organizational behavior and has been investigated in many papers worldwide and in different work environments.

The organizational climate and the working conditions are fundamental factors for the growth and development of personnel, for this reason, job satisfaction is an important component in the workplace (Cabrera et al., 2004). The study of job satisfaction requires focusing attention on the conditions or elements of the work environment to be able to refer to the responses derived from these specific stimuli. It is also a relevant aspect among the hospitals staff, since the presence of satisfaction links to their effectiveness, innovation and adaptation (Chiang et al., 2007).

Organizational factors and individual perceptions affect individual attitudes within organizations. Organizational factors are a series of elements that are developed within an organization (Castillo et al., 2013), as are the elements of the organizational climate. During the twentieth century, many researches focused on the relationships between organizational factors and job satisfaction were developed (Alfaro De Prado and Vecino, 1999, Chiang et al., 2007, Fernández et al., 1995, Figueiredo-Ferraz et al., 2012, Gandarillas et al., 2014, Molina et al., 2009, Ostroff, 1992, Salgado et al., 1996, Villagómez, et al., 2003, Yáñez et al., 2010).

Various relationships between the dimensions and variables mentioned above have been disclosed. Based on the investigations reviewed to carry out this research, organizational factors and individual perceptions that could influence personnel performance and organizational commitment through job satisfaction, in the context of university hospitals, were selected.

It is also important to mention the university hospitals characteristics because, unlike other hospitals, a university hospital is affiliated with a university, generally public, for which, its philosophy shows commitment and dedication to assistance, teaching and medical research, focusing on the theoretical-practical training of undergraduate and graduate students (Martínez, 2002).

The teaching and research practices carried out in these hospitals commit them to provide a good service, since they seek to work under quality standards and service continuous improvement, following the application of the medical advances coming from the research carried out in them and the training of health professionals.

Due to these characteristics, university hospitals have certain working conditions that incur personnel commitment and the inherent responsibilities of the job, reflected in the offered service (Medina M.L. et al., 2015).

In another instance, among the professional health personnel in university hospitals, a large number of professionals from different branches of the medical area can be find, for example, nurses, doctors, clinical chemists, among others.

These professionals' activities require great responsibility and generate physical exhaustion, because when acquiring the responsibility of working for a university hospital, they are committed not only to deal with ethics and professionalism with patients, but also to collaborate in the practical-professional training of undergraduate and graduate students.

The results of this research will be a contribution to knowledge for human resource management, especially university hospitals, school-hospitals, and any public and private hospital in Mexico. This in relation to the attention 
of the organizational factors and the individual perceptions of the personnel, as well as the organizational behavior issues.

So far, the investigations carried out in a similar context in Mexico are reduced, which justifies the accomplishment of this study, as highlighted by Rositas et al. (2006) and Creswell (2009).

On the other hand, the statistical method of partial least squares structural equation modeling (PLS-SEM) considers the recent recommendations to evaluate the parameters of the mediating effects of variables in structural equation modeling, measuring the impacts between the variables of interest (Hair et al., 2017). In addition, the choice of this method is the one indicated when there are correlations among the mediating variable and the other variables of a model (Hayes, 2013). Therefore, the analysis of the collected data and the results also justify the accomplishment of the research, being a methodological contribution for future research.

Based on the above, the general research objective is the following: to determine that organizational factors and individual perceptions influence personnel performance and organizational commitment through job satisfaction of professional health personnel working in university hospitals.

The contribution achieved with the fulfillment of the general objective will allow to integrate the results to a practical level in human resource management, mainly in hospitals with assistance, teaching and research purposes.

As a general hypothesis it is defined that: "Organizational factors such as: recognition and participation in decisionmaking, in addition to individual perceptions such as: identification and affection for the organization, positively impact on personnel performance and organizational commitment through job satisfaction of professional health personnel in university hospitals". Six specific hypotheses were also defined, which positively relate each of the independent variables, described in the literature review, to personnel performance and organizational commitment through job satisfaction. These are detailed in the results section.

\section{Literature Review:-}

The dependent variables in this study are personnel performance and organizational commitment, job satisfaction as a mediating variable, and three independent variables: recognition, participation in decision-making and identification and affection for the organization. Below, each of them is detailed.

\section{Personnel performance}

Because the concept of performance that is handled throughout this investigation exclusively involves the personnel individual results, influenced by their behavior, personnel performance is defined as the effectiveness of an individual to carry out the activities and responsibilities inherent in his job (AbuAlRub, 2004, AbuAlRub and AlZaru, 2008).

Shore and Martin (1989) presented correlations between job satisfaction and performance $(\mathrm{r}=0.26, \mathrm{p}<0.025)$, and less strong correlations between organizational commitment and performance $(r=0.05, p<0.05)$. A study conducted by Meyer et al. (1989) shows a significant correlation between affective commitment and work performance $(\mathrm{r}=$ $0.25, \mathrm{p}<0.05)$.

Ostroff (1992) analyzed the relationship between satisfaction, commitment and performance in the United States, obtaining a positive relationship between satisfaction and performance. Leung (1997) developed an empirical study in Hong Kong to demonstrate the relationship between some components of organizational behavior and performance. Another work by Kim (2004) shows a positive correlation between job satisfaction and performance (b $=0.360, \mathrm{p}<0.001)$.

Salgado (2006) mentioned that performance has certain determinants related to the work environment conditions. Research conducted in Jordan has studied the performance of nurses as an important variable in the health context (AbuAlRub, 2004, AbuAlRub and Al-Zaru, 2008).

Another study showed relationships among organizational behavior components and performance (Leung et al., 2008), concluding that, taken together, they are indicators of the results obtained by the organization. 
Ismail et al. (2011) verified the relationship between performance and other attitudes arising from organizational behavior. Dalal et al. (2012) conducted a study observing that organizational commitment is a precedent for performance.

Another empirical work indicated that satisfaction $(b=0.724, p<0.05)$ and commitment $(b=0.262, p<0.05)$ have a positive effect on job performance (Susanty and Miradipta, 2013). Previous works show that performance has been influenced on numerous occasions by job satisfaction.

\section{Organizational commitment}

Based on what authors such as Mowday et al. (1982), Toro (1998) and Chiang et al. (2010) pointed out, organizational commitment is defined as the favorable disposition of an individual to experience interest in the responsibilities of his position and towards the organization, which also allows him to identify himself and to be linked to it.

Several works show relationships between organizational commitment and the other research variables. As an example, in Canada, some organizational commitment components were studied, considering the emotional bond, identification and participation within the organization among other variables (Meyer et al., 1989).

Locke (1997) proposed a complex model focused on a theory of motivation in which he presented the relationship between performance, satisfaction and commitment, noting that performance was a cause of satisfaction and in turn, was a cause of organizational commitment. Toro (1998) conducted a study where he investigated the relationship between the sense of belonging, interpersonal relationships and retribution, as well as its effects on employee commitment, identifying highly significant correlations $(\mathrm{p}<0.0001)$.

A meta-analysis conducted by Riketta (2002) presented a relationship between attitudinal commitment and work performance. In another review, López-Araujo et al. (2007) stated that satisfaction and commitment are reciprocally related, so that when there is satisfaction with the work performed by personnel, a sense of commitment to the organization develops, and vice versa.

Other investigations have indicated causal relationships between commitment and job satisfaction (Mañas et al., 2007, Rad and De Moraes, 2009). Kim (2004) showed a positive correlation between job satisfaction and organizational commitment $(r=0.629, \mathrm{p}<.01)$. In another work, Ismail et al. (2011) presented positive relationships between organizational commitment, satisfaction and performance.

\section{Job satisfaction}

Job satisfaction is an attitude or set of attitudes developed by an individual towards his work situation and which can be oriented towards work in general or specific aspects of it (Bravo et al., 1996). Numerous works involve the study of the relationships of job satisfaction with many other variables.

In one of them, Mowday et al. (1979) observed that satisfaction and commitment are related constructs. Later, Ostroff (1992) measured satisfaction of teachers, considering satisfaction with co-workers, supervision, salary, administration, opportunity for professional growth, physical resources, and communication, among other variables.

Leung (1997) conducted a study on a sample of workers in clothing stores in Hong Kong, observing a high correlation between satisfaction and performance $(r=.72)$. In Spain, a study on job satisfaction was carried out in two companies, one private and one public. The results indicated that the variables that generated the highest satisfaction rate among the employees of both companies were self-esteem, the prestige of the position outside of the organization, security in the position, the importance of work, and friendship ties (Alfaro De Prado and Vecino, 1999).

The work done by Morris and Bloom (2002) reflected the relationship between some organizational factors, satisfaction, and organizational commitment, highlighting the importance of certain organizational factors as a background of personnel performance.

In Mexico, the dimensions of achievement, recognition, and training were identified as determinants of satisfaction in physicians (Villagómez et al., 2003). The work of Kim (2004) also highlighted the evaluation of affective 
commitment through an instrument consisting of items related to the identification and affection for the organization, related to job satisfaction.

A study developed by Betanzos et al. (2006) distinguished the concept of identification with the organization and that of affection for the organization as components of personnel work perceptions. Chiang et al. (2007) used variables such as the relationship with superiors, the physical environment, participation in decisions, personal work, and recognition, observing significant relationships between each of them and job satisfaction $(\mathrm{p}<0.05)$.

Yáñez et al. (2010) developed a study to evaluate interpersonal relationships and job satisfaction using two variables: the relationship with leaders and the relationship with the pairs, observing significant correlations. The work of Ismail et al. (2011) showed the relationship between satisfaction and performance in their model. Susanty and Miradipta (2013) showed that job satisfaction has a significant positive effect on job performance $(b=0.724, p$ $<0.05)$.

Some studies showed that satisfaction improves work life, reflected in job performance (Cetina-Tabares et al., 2006, Formosa et al., 2014, Herrera-Amaya and Manrique-Abril, 2008; Juárez-Adauta, 2012; Nava-Galán et al., 2013). Figueiredo-Ferraz et al. (2012) took as causal variables of satisfaction: supervision, physical environment, benefits, intrinsic aspects, and participation.

Also in Spain, Gandarillas et al. (2014) found different significant correlations ( $\mathrm{p}<0.0005)$ between organizational climate variables and job satisfaction. Works as those of Cetina-Tabares et al. (2006), Figueiredo-Ferraz et al. (2012), Gandarillas et al. (2014), Herrera-Amaya and Manrique-Abril (2008), Juárez-Adauta (2012), López-García, Valdez-Martínez, Goycochea-Robles and Bedolla (2009), Mañas et al. (2007), and Molina et al. (2009), indicatedz that the degree of measurement of commitment and/or job satisfaction is proportional to the personnel results, within which performance is distinguished.

Some studies allude to a certain relationship between commitment and job satisfaction in which both, at the same time, are involved in the results and personnel performance (Cújar et al., 2013; Hauser, 2014; Meyer et al., 2006; Nava-Galán et al., 2013; Sánchez-Sellero M., Sánchez-Sellero P., Cruz-González and Sánchez-Sellero F., 2014).

\section{Recognition}

Recognition is the assessment of the particularities and abilities of an individual, which allow him to make contributions to the organization (Saldarriaga, 2014).

Alonso (2008) conducted a study concluding that women showed a high degree of satisfaction with regard to job recognition, although they did not reflect significant differences. On the other hand, the less senior staff was less satisfied with the recognition.

In a Chilean study, autonomy and recognition were evaluated, and statistically significant relationships were observed with the commitment (Chiang et al., 2010). The relationship between recognition and commitment was stronger in men $(r=0.559, \mathrm{p}<0.01)$ than in women $(\mathrm{r}=0.461, \mathrm{p}<0.05)$.

\section{Participation in decision-making}

Starting from the definitions of Boria-Reverter et al. (2012), participation in decision-making is understood as the possibility of an individual being a participant in decisions related to the activities that he carries out and that involve his initiative.

The work of Boria-Reverter et al. (2012) showed a positive relationship between participation in decision-making and job satisfaction in company managers, scientific, and intellectual technicians.

An empirical study conducted in Spain by Muñiz et al. (2014), evaluated organizational climate dimensions, reporting a significant relationship between employee participation and good working environment $(\mathrm{t}=7.90, \mathrm{p}$ $<0.001$ ), warning about the impact that work climate can have on the personnel satisfaction.

Identification and affection for the organization

The definition of identification and affection by the organization is specified as: the degree of acceptance of organizational values and the identification that a person has with his position and organization, as well as the 
feelings and perceptions of pleasure and happiness that an individual manifest when belonging to an organization (Betanzos et al., 2006).

In the works carried out by Betanzos et al. (2006), Kim (2004) and Mowday et al. (1979) the sense of identification and that of affection for the organization were presented as separate variables, being determinants of organizational commitment.

Dávila and Jiménez (2014) carried out a study to verify the relationship between the sense of identification with the organization, the affection for the organization, and commitment. The results showed significant correlations between the sense of identification $(r=-0.245, \mathrm{p}<0.01)$ and organizational commitment, as well as between the affection for the organization $(\mathrm{r}=-0.283, \mathrm{p}<0.01)$ and organizational commitment.

Based on the literature review, the graphic model of the research is presented (Fig. 1).

Fig. 1:- Proposed graphic model

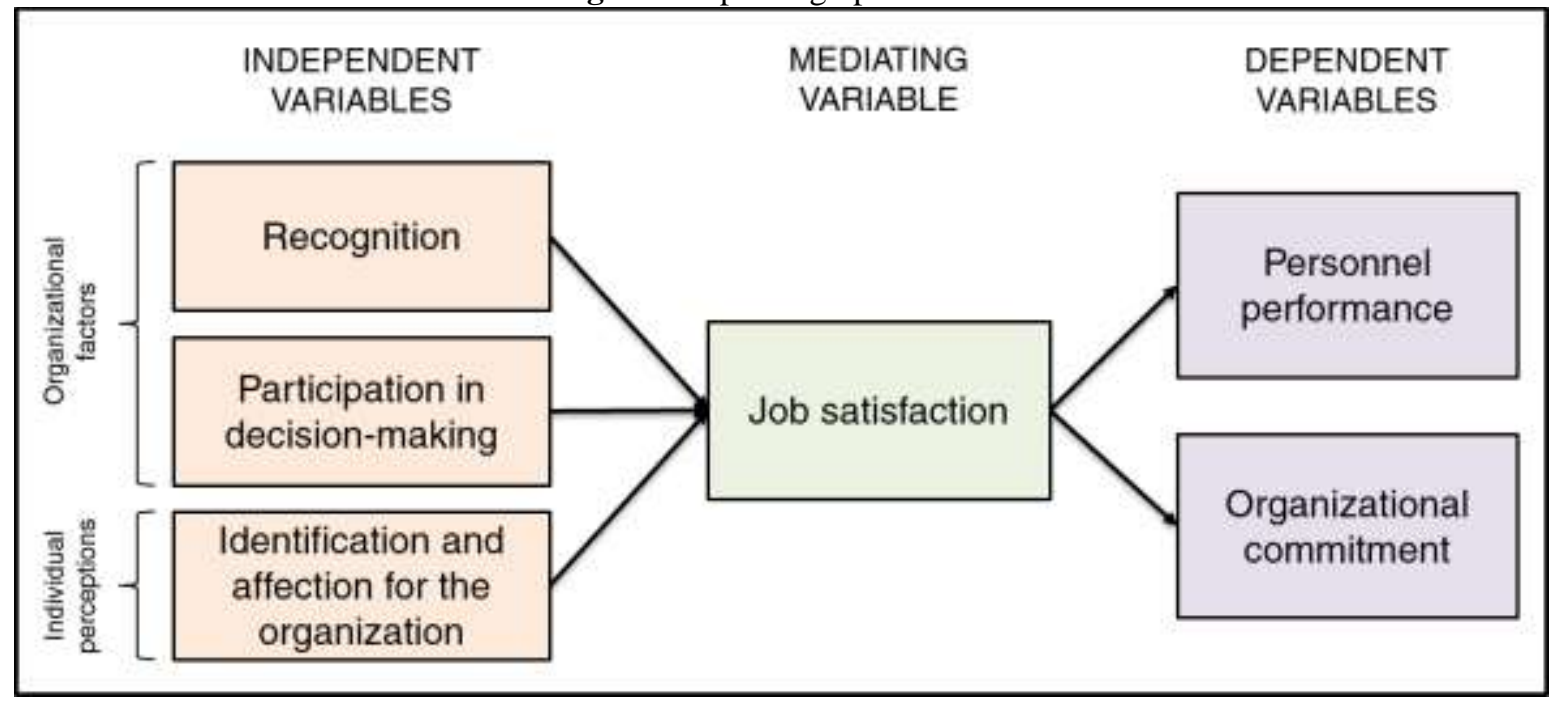

As a practical support for the research, the following methodological objectives were specified:

1. Analyze the research problem background.

2. Review and theoretically support the research variables.

3. Prepare and validate an instrument to measure the research variables.

4. Apply the measurement instrument in the population of interest for the research.

5. Analyze the data obtained with the measurement instrument using the relevant statistical technique.

6. Develop the results of the data analysis to elaborate conclusions and theoretical contributions.

\section{Material and Methods:-}

This research has a quantitative approach, an exploratory, descriptive, correlational, and explanatory scope, as well as a transeccional and non-experimental design. Surveys (measurement instruments) were applied to obtain the necessary data and explain the relationship between the research variables.

The instrument developed for data collection was integrated into two sections. Section 1 collected the participant general information: age, seniority, gender, marital status, type of employee, educational level, and degree specification. Section 2 contained 35 items, corresponding to the six research variables. The answers for all items had a 5-point Likert scale, where 1 indicated "Strongly disagree" and 5 "Strongly agree".

The survey was developed based on the review of scales implemented in other research works, regarded their reliability. Subsequently, the validity of its content was carried out, with the participation of human resource managers to evaluate the relevance of the items with respect to their research variable, as well as their drafting.

The study population included all the health professional personnel of two university hospitals, located in northeastern Mexico (including the largest in the country), with a total of 926 elements. The estimate of the sample was 182 . The sampling was non-probabilistic since it was not possible to randomly select the participants. 
The inclusion criteria of the participants were three: 1) health professional personnel working in one of the described university hospitals, 2) must had a healthcare bachelor's degree, and 3) more than one year of seniority.

A pilot test was carried out on 51 health professionals from one of the described university hospitals; all participants in the pilot test met the inclusion criteria. The reliability analysis was carried out, obtaining Cronbach's Alpha indexes between 0.7 and 0.9 for each research variable, using the statistical software SPSS (Statistical Package for the Social Sciences), version 21, so the survey application was continued.

The data collection process was carried out during September 2016 - February 2017, as well as in November 2017. It was carried out during the work shifts of the participants: morning, afternoon, and night. Participation request was direct and personal; their collaboration was totally voluntary. The total number of completely answered surveys was 235 .

The analysis methods that were carried out were demographic and statistical. For the statistical analysis, a method of structural equations, model of second order factors, was used (Chin, 1998) through the statistical software SmartPLS 3 (Ringle et al., 2015).

\section{Results:-}

The demographic characteristics analysis of health professional personnel showed that participants had an age range of 20 to 64 years, with an average age of 38, the majority belonging to the range between 20 and 29 years. Regarding seniority, participants had between 1 and 37 years, with an average of 13, the majority belonging to the range of 1 to 10 years. Female gender was the largest part of the sample with 74\%. Regarding the type of employment contract, $77 \%$ had permanent contracts.

In another instance, $60 \%$ of the participants said that were married, followed by $31 \%$ who were single, and the rest were divorced, widowed, separated or living in a free union. Regarding the level of studies, $74 \%$ had only undergraduate degrees, followed by $16 \%$ that had medical specialty or master's degree and the rest had a fellowship or doctorate. Just over half had a nursing bachelor's degree (54\%), followed by physicians (21\%), and clinical chemists $(19 \%)$.

Statistical analysis of structural equations

The statistical results of SEM include the measurement model and the structural model analysis.

\section{Evaluation of the measurement model}

Reflective models are characterized by the internal consistency reliability and validity assessments. Specific measurements include composite reliability, convergent validity and discriminant validity (Hair et al., 2017).

Internal consistency reliability

Hair et al., (2017) recommend reporting Cronbach's Alpha and composite reliability to assess internal consistency. The results obtained for both criteria were in a range between 0.74 and 0.90 , so the average results for each latent variable were acceptable for this criterion.

\section{Convergent validity}

To determine convergent validity, the outer indicator loadings, the average variance extracted (AVE), and the communality values of the items were considered (Hair et al., 2017). The outer loadings for all indicators were above 0.708 , as well as communality values were above 0.50 .

The AVE values for the constructs were above 0.50 , in a range between 0.60 and 0.72 , being the minimum value for the personnel performance variable and the maximum value for the recognition variable.

Discriminant validity

The first assessment was the cross-loadings criterion, which established discriminant validity since each indicator loaded high on its corresponding construct. The second criterion was the Fornell-Larcker, which was also acceptable. 
To guarantee the discriminant validity results, Hair et al. (2017) propose assessing the heterotrait-monotrait ratio (HTMT) of the correlations, as well as their confidence intervals, both being acceptable in this research. Table 1 summarizes the reflective measurement model results.

Table 1:- Results summary for reflective measurement model

\begin{tabular}{|l|l|l|l|l|l|l|}
\hline Indicator & Convergent validity & Internal consistency reliability & $\begin{array}{l}\text { Discriminant } \\
\text { validity? }\end{array}$ \\
\hline & $\begin{array}{l}\text { Outer } \\
\text { loadings }\end{array}$ & Communality & AVE & $\begin{array}{l}\text { Cronbach's } \\
\text { Alpha }\end{array}$ & $\begin{array}{l}\text { Composite } \\
\text { reliability }\end{array}$ & \\
\hline & $>0.708$ & $>0.50$ & $>0.50$ & $0.60-0.90$ & $0.60-0.90$ & $\begin{array}{l}\text { HTMT } \\
\text { Confidence } \\
\text { interval }\end{array}$ \\
\hline
\end{tabular}

\section{Evaluation of the structural model}

Structural model results evaluation allows to determine the capacity of the model to predict one or more of its constructs. The assessment procedure included collinearity, the significance and relevance of the structural model relationships, level of $R^{2}, f^{2}$ effect size, and predictive relevance $Q^{2}$ (Hair et al., 2017).

Collinearity assessment

The measure of collinearity was done through the variance inflation factor (VIF), reciprocal to the tolerance value. Table 2 shows the VIF and tolerance values for all indicators, they are below 5 and above 0.20 , respectively, both values being acceptable for all indicators.

Table 2:- Collinearity assessment: VIF and tolerance values

\begin{tabular}{|c|c|c|}
\hline \multirow{2}{*}{\multicolumn{3}{|c|}{$\begin{array}{l}\text { Indicator } \\
\text { Personnel performance }\end{array}$}} \\
\hline & & \\
\hline 1DES & 1.584 & 0.631 \\
\hline
\end{tabular}




\begin{tabular}{|c|l|l|}
\hline 8DES & 1.424 & 0.702 \\
\hline 22DES & 1.591 & 0.629 \\
\hline 29DES & 1.526 & 0.655 \\
\hline Organizational commitment & 2.126 & 0.470 \\
\hline 10CO & 2.233 & 0.448 \\
\hline 17CO & 1.935 & 0.517 \\
\hline 31CO & 1.821 & 0.549 \\
\hline 35IDAF & 1.899 & 0.527 \\
\hline Job satisfaction & 1.913 & 0.523 \\
\hline 2SL & 2.639 & 0.379 \\
\hline 9SL & 1.917 & 0.522 \\
\hline 16SL & 1.542 & \\
\hline 23SL & 2.126 & 0.648 \\
\hline 13REC & 1.966 & 0.470 \\
\hline Recognition & 1.908 & 0.509 \\
\hline 34REC & 1.851 & \\
\hline \multicolumn{2}{|l|}{} & 0.524 \\
\hline Participation in decisión-making & 1.766 & 0.540 \\
\hline 5PART & 1.451 & 0.566 \\
\hline 12PART & 1.578 & 0.689 \\
\hline 19PART & 1.556 & 0.634 \\
\hline 26PART & 1.399 & 0.642 \\
\hline Identification and affection for the organization & 0.715 \\
\hline 14DAF &
\end{tabular}

Structural model path coefficients

The estimates of the path coefficients are obtained with the PLS-SEM algorithm, representing the hypothetical relationships among the constructs. Table 3 summarizes the results of the significance tests, including path coefficients, $t$ values, $p$ values, and 95\% confidence intervals for all the structural model relationships, resulting only six relationships at a significant level.

Coefficient of determination $\left(R^{2}\right.$ value $)$

Table 4 shows the $R^{2}$ values for the three endogenous latent variables and the average of the $R^{2}$ values of the model, the latter being moderate, equal to 0.50 .

Effect size $f^{2}$

Table 5 shows the $f^{2}$ effect size for the structural model relationships. Recognition and participation in decisionmaking had small effects on job satisfaction (close to 0.02). On the other hand, identification and affection for the organization had a medium effect on job satisfaction (close to 0.15). Finally, identification and affection for the organization and job satisfaction had large effects on organizational commitment (close to 0.35), as well as job satisfaction on personnel performance.

Predictive relevance $Q^{2}$

Stone-Geisser's $Q^{2}$ value is obtained from the blindfolding procedure, which represents a criterion for evaluating the predictive relevance of cross-loadings for a PLS path model. Table 4 shows the $Q^{2}$ values for the endogenous latent variables of the path model, representing predictive relevance for all three.

Table 3:- Significance of the structural model relationships

\begin{tabular}{|l|l|l|l|l|l|}
\hline $\begin{array}{l}\text { Structural model } \\
\text { relationships }\end{array}$ & Path coefficients & $95 \%$ Confidence intervals & $t$ value & $p$ value & $\begin{array}{l}\text { Significance } \\
(\mathrm{p}<0.05)\end{array}$ \\
\hline REC $->$ DES & 0.022 & {$[-0.131,0.174]$} & 0.275 & 0.783 & No \\
\hline REC $->$ CO & 0.079 & {$[-0.046,0.196]$} & 1.321 & 0.187 & No \\
\hline
\end{tabular}




\begin{tabular}{|l|l|l|l|l|l|}
\hline REC $->$ SL & -0.192 & {$[-0.354,-0.053]$} & 2.539 & 0.011 & Yes \\
\hline PART -> DES & 0.155 & {$[-0.006,0.304]$} & 1.958 & 0.050 & No \\
\hline PART -> CO & -0.096 & {$[-0.226,0.033]$} & 1.461 & 0.144 & No \\
\hline PART -> SL & 0.323 & {$[0.152,0.509]$} & 3.601 & 0.000 & Yes \\
\hline IDAF - DES & 0.108 & {$[-0.042,0.256]$} & 1.408 & 0.159 & No \\
\hline IDAF -> CO & 0.459 & {$[0.319,0.605]$} & 6.354 & 0.000 & Yes \\
\hline IDAF -> SL & 0.462 & {$[0.254,0.617]$} & 5.034 & 0.000 & Yes \\
\hline SL -> DES & 0.482 & {$[0.334,0.616]$} & 6.552 & 0.000 & Yes \\
\hline SL -> CO & 0.519 & {$[0.366,0.655]$} & 7.078 & 0.000 & Yes \\
\hline
\end{tabular}

Note. DES, personnel performance; CO, organizational commitment; SL, job satisfaction; REC, recognition; PART, participation in decision-making; IDAF, identification and affection for the organization.

Table 4:- Model's $R^{2}$ values and predictive relevance: $Q^{2}$ value

\begin{tabular}{|l|l|l|}
\hline Latent variable & $R^{2}$ value & $Q^{2}$ value \\
\hline Personnel performance & 0.438 & 0.236 \\
\hline Organizational commitment & 0.714 & 0.457 \\
\hline Job satisfaction & 0.356 & 0.226 \\
\hline \multicolumn{1}{|c|}{ Average } & 0.502 & \\
\hline
\end{tabular}

Table 5:- Effect size $f^{2}$

\begin{tabular}{|l|l|}
\hline Latent variables relationship & Effect size $f^{2}$ \\
\hline REC $->$ DES & 0.000 \\
\hline REC $->$ CO & 0.010 \\
\hline REC $->$ SL & 0.027 \\
\hline PART -> DES & 0.017 \\
\hline PART $->$ CO & 0.013 \\
\hline PART - SL & 0.069 \\
\hline IDAF -> DES & 0.009 \\
\hline IDAF -> CO & 0.318 \\
\hline IDAF -> SL & 0.167 \\
\hline SL $>$ DES & 0.266 \\
\hline SL $>$ CO & 0.606 \\
\hline
\end{tabular}

Note. DES, personnel performance; CO, organizational commitment; SL, job satisfaction; REC, recognition; PART, participation in decision-making; IDAF, identification and affection for the organization.

\section{Mediation effects}

The testing of the mediation model included the assessment of the significance of the direct and indirect effects (via the mediator variable) among the constructs (Table 6).

The results showed that the six hypothetical relationships had significant indirect effects, five of them being full mediations and only one as a partial mediation. These results define which research hypotheses were rejected and which were accepted. Table 7 shows the research hypotheses testing. 
Table 6:- Significance analysis results of the direct and indirect effects

\begin{tabular}{|l|l|l|l|l|l|l|l|l|}
\hline $\begin{array}{l}\text { Structural } \\
\text { model } \\
\text { relationships }\end{array}$ & $\begin{array}{l}\text { Direct } \\
\text { effect }\end{array}$ & $\begin{array}{l}\text { 95\% } \\
\text { Confidence } \\
\text { interval }\end{array}$ & $\begin{array}{l}t \\
\text { value }\end{array}$ & $\begin{array}{l}\text { Significance } \\
(\mathrm{p}<0.05)\end{array}$ & $\begin{array}{l}\text { Indirect } \\
\text { effect }\end{array}$ & $\begin{array}{l}95 \% \\
\text { Confidence } \\
\text { interval }\end{array}$ & $\begin{array}{l}t \\
\text { value }\end{array}$ & $\begin{array}{l}\text { Significance } \\
(\mathrm{p}<0.05)\end{array}$ \\
\hline REC -> DES & 0.022 & $\begin{array}{l}{[-0.131,} \\
0.174]\end{array}$ & 0.275 & No & -0.093 & $\begin{array}{l}{[-0.190, \quad-} \\
0.025]\end{array}$ & 2.295 & Yes \\
\hline REC -> CO & 0.079 & $\begin{array}{l}{[-0.046,} \\
0.196]\end{array}$ & 1.321 & No & -0.100 & $\begin{array}{l}{[-0.199,} \\
0.029]\end{array}$ & -2.384 & Yes \\
\hline $\begin{array}{l}\text { PART -> } \\
\text { DES }\end{array}$ & 0.155 & $\begin{array}{l}{[-0.006,} \\
0.304]\end{array}$ & 1.958 & No & 0.156 & $\begin{array}{l}{[0.066,} \\
0.273]\end{array}$ & 2.957 & Yes \\
\hline PART -> CO & -0.096 & $\begin{array}{l}{[-0.226,} \\
0.033]\end{array}$ & 1.461 & No & 0.168 & $\begin{array}{l}{[0.074,} \\
0.292]\end{array}$ & 3.121 & Yes \\
\hline $\begin{array}{l}\text { IDAF -> } \\
\text { DES }\end{array}$ & 0.108 & $\begin{array}{l}{[-0.042,} \\
0.256]\end{array}$ & 1.408 & No & 0.223 & $\begin{array}{l}{[0.115,} \\
0.346]\end{array}$ & 3.754 & Yes \\
\hline IDAF -> CO & 0.459 & $\begin{array}{l}{[0.319,} \\
0.605]\end{array}$ & 6.354 & Yes & 0.240 & $\begin{array}{l}{[0.122,} \\
0.372]\end{array}$ & 3.727 & Yes \\
\hline
\end{tabular}

Note. DES, personnel performance; CO, organizational commitment; SL, job satisfaction; REC, recognition; PART, participation in decision-making; IDAF, identification and affection for the organization.

Table 7:- Research hypotheses testing

\begin{tabular}{|c|c|c|}
\hline Research hypotheses & Effect & $\begin{array}{l}\text { Hypotheses } \\
\text { testing }\end{array}$ \\
\hline $\begin{array}{l}\text { H1: Recognition positively impacts personnel performance through } \\
\text { job satisfaction }\end{array}$ & $\begin{array}{l}\text { Significant } \\
\text { mediation }\end{array}$ & Rejected* \\
\hline $\begin{array}{l}\text { H2: Recognition positively impacts organizational commitment } \\
\text { through job satisfaction }\end{array}$ & $\begin{array}{l}\text { Significant } \\
\text { mediation }\end{array}$ & Rejected* \\
\hline $\begin{array}{l}\text { H3: Participation in decision-making positively impacts personnel } \\
\text { performance through job satisfaction }\end{array}$ & $\begin{array}{l}\text { Significant } \\
\text { mediation }\end{array}$ & Accepted \\
\hline $\begin{array}{l}\text { H4: Participation in decision-making positively impacts } \\
\text { organizational commitment through job satisfaction }\end{array}$ & $\begin{array}{l}\text { Significant } \\
\text { mediation }\end{array}$ & Accepted \\
\hline $\begin{array}{l}\text { H5: Identification and affect for the organization positively impacts } \\
\text { personnel performance through job satisfaction }\end{array}$ & $\begin{array}{ll}\begin{array}{l}\text { Significant } \\
\text { mediation }\end{array} & \text { full } \\
\end{array}$ & Accepted \\
\hline $\begin{array}{l}\text { H6: Identification and affect for the organization positively impacts } \\
\text { organizational commitment through job satisfaction }\end{array}$ & $\begin{array}{l}\text { Significant partial } \\
\text { mediation, complemetary } \\
\text { mediation }\end{array}$ & Accepted \\
\hline
\end{tabular}

*Statistically significant relationship with a negative impact.

\section{Discussion:-}

Under the methodological strategy, it can be defined that participation in decision-making and the sense of identification and affection for the organization are issues that determine personnel performance and organizational commitment through job satisfaction. On the other hand, recognition, despite having a significant impact on performance and commitment through job satisfaction, due to the negative impact, follows that is not part of the important issues for health professional personnel to be able to have good performance and be committed to the organization.

It is important that human resource managers recognize that the university hospitals environment is different from that of other organizations in the health sector, basically because personnel showed they have an appreciation for the institution, since, despite the fact that most of them were professionally trained in their actual workplace, as employees they obtain work benefits that are added to the bond that already existed between the individuals and the hospital. This does not imply that personnel is not interested in being recognized in their work, rather it states that being recognized is not necessary to have a good performance and feel committed to work.

For practical questions, this knowledge helps human resource managers of medical institutions with a focus on assistance, teaching, and research, to identify the organizational issues and perceptions that, according to 
professional health personnel, are important to determine their good performance and feel committed to the organization.

\section{Conclusion:-}

The promotion of participation in decision-making and the development of a sense of identification and affection for the organization are aspects to consider among health professional personnel of university hospitals to obtain better individual results and, in this way, offer better health services, teaching development and greater achievements in research area.

The results of this study, the effects of participation in decision-making and the sense of identification and affection for the organization on personnel performance and organizational commitment through job satisfaction is an issue that still has much to explore. Mainly the relationship that involves the identification and affection for the organization variable, which was designed specifically for this research, but can be further explored in this and other contexts, in terms of its impact on personnel results.

The above, also provides useful information for human resource managers, considering issues that have not been studied in other investigations. The inclusion of aspects of organizational climate, organizational behavior, and individual results in the same model allows the development of research that can be replicated in other university hospitals or even in other sectors, nationally or internationally.

\section{References:-}

1. AbuAlRub, R. F., (2004). Job stress, job performance, and social support among hospital nurses. Journal of Nursing Scholarship, 36(1), 73-78.

2. AbuAlRub, R. F. \& Al-Zaru, I. M., (2008). Job stress, recognition, job performance and intention to stay at work among Jordanian hospital nurses. Journal of Nursing Management, 16, 227-236. DOI: 10.1111/j.13652834.2007.00810.x

3. Alfaro De Prado, A. M. \& Vecino, J. D., (1999). Medición de la satisfacción laboral mediante el cuestionario de satisfacción de necesidades de Porter. Revista de Psicología del Trabajo y de las Organizaciones, 15(1), 63-75.

4. Alonso, P., (2008). Estudio comparativo de la satisfacción laboral en el personal de administración. Revista de Psicología del Trabajo y de las Organizaciones, 24(1), 25-40.

5. Arias, F., (2006). Liderazgo para la competitividad y el compromiso. En F. Arias (6 ${ }^{\mathrm{a}}$ ed), Administración de recursos humanos: Para el alto desempeño (pp. 203-221). México: Trillas.

6. Betanzos, N., Andrade, P. \& Paz, F., (2006). Compromiso organizacional en una muestra de trabajadores mexicanos. Revista de Psicología del Trabajo y de las Organizaciones, 22(1), 25-33.

7. Boria-Reverter, S., Crespi-Vallbona, M. \& Mascarilla-Miró, O., (2012). Variables determinantes de la satisfacción laboral en España. Cuadernos de Economía, 35, 9-16.

8. Bravo, M. J., Peiró, J. M. \& Rodríguez, I., (1996). Satisfacción laboral. En J. M. Peiró y F. Prieto (eds), Tratado de psicología del trabajo, 1. La actividad laboral en su contexto (pp. 343-394). España: Ed. Síntesis S.A.

9. Cabrera, C. E., Franco, S. A., González, G., Vega, G., Parra, J. \& Íñiguez, J. E., (2004). Satisfacción laboral de profesionales de la salud en el IMSS, Jalisco. Rev Med IMSS, 42(3), 193-198.

10. Castillo, V. H., Varela R. A. \& Manzanilla L., (2013). Factores organizacionales: su impacto en la estrategia de equipos de trabajo. XVIII Congreso Internacional de Contaduría, Administración e Informática.

11. Cetina-Tabares, R. E., Chan-Canul, A. G. \& Sandoval-Jurado, L., (2006). Nivel de satisfacción laboral y síndrome del desgaste profesional en médicos familiares. Rev Med IMSS, 44(6), 535-540.

12. Chiang, M., Núñez, A., Martín, M. J. \& Salazar, M., (2010). Compromiso del trabajador hacia su organización y la relación con el clima organizacional: Un análisis de género y edad. Panorama Socioeconómico, 40, 92-103.

13. Chiang, M. M., Salazar, C. M. \& Núñez, A., (2007). Clima organizacional y satisfacción laboral en un establecimiento de salud estatal Tipo 1. Theoria, 16(2), 61-76.

14. Chin, W. W., (1998). Issues and opinion on structural equation modeling. Management Information Systems Quarterly, 22(1), 7-16.

15. Creswell, J. W., (2009). The Introduction. En J. Creswell (3a ed), Research design: Qualitative, quantitative, and mixed methods approaches. Thousand Oaks: Sage Publications.

16. Cújar, A. D., Ramos, C. D., Hernández, H. E. \& López, J. M., (2013). Cultura organizacional: Evolución en la medición. Estudios Gerenciales, 29, 350-355. 
17. Dalal, R. S., Baysinger, M., Brummel, B. J. \& LeBreton, J. M., (2012). The relative importance of employee engagement, other job attitudes, and trait affect as predictors of job performance. Journal of Applied Social Psychology, 42(1), 295-325.

18. Dávila, C. \& Jiménez, G., (2014). Sentido de pertenencia y compromiso organizacional: predicción del bienestar. Revista de Psicología, 32(2), 272-302.

19. Fernández, M. I., Villagrasa, J. R., Fe, M., Vázquez, J., Cruz, E., Aguirre, M. V. \& Andradas, V., (1995). Estudio de la satisfacción laboral y sus determinantes en los trabajadores sanitarios de un área de Madrid. Rev Esp Salud Pública, 69, 487-497.

20. Figueiredo-Ferraz, H., Grau-Alberola, E., Gil-Monte, P. R. \& García-Juesas J. A., (2012). Síndrome de quemarse por el trabajo y satisfacción laboral en profesionales de enfermería. Psicothema, 24(2), 271-276.

21. Formosa, C., Caruana, D. \& Chockalingam, N., (2014). Determinants of job satisfaction in different podiatric clinical settings. Revista Internacional de Ciencias Podológicas, 8(2), 91-98.

22. Gandarillas, M., Vásquez, L., Márquez, H., Santamaría, E., Garaña, O. \& Santibánez, M., (2014). Satisfacción laboral y apoyo social en trabajadores de un hospital de tercer nivel. Med Segur Trab, 60(243), 64-89.

23. González-Garza, M., (2006). La administración de la calidad en la atención de la salud. Hospitalidad-ESDAI, 31-59.

24. Griffin, R. W. \& Moorhead G., (2010). Panorama del comportamiento organizacional. En R. W. Griffin y G. Moorhead ( $9^{\mathrm{a}}$ ed), Comportamiento organizacional: Gestión de personas y organizaciones (pp.1 - 21). México: Cengage Learning.

25. Hair, J. F., Hult, G. T. M., Ringle, C. M. \& Sarstedt, M., (2017). A primer on partial least squares structural equation modeling (PLS-SEM), $2^{\text {a }}$ Edición, Estados Unidos, SAGE.

26. Hauser, L., (2014). Work motivation in organizational behavior. Economics, Management, and Financial Markets, 9(4), 239-246.

27. Hayes, A. F., (2013). Introduction to Mediation, Moderation and Conditional Process Analysis: A RegressionBased Approach, $1^{\text {a }}$ Edición, Estados Unidos, The Guildford Press.

28. Herrera-Amaya, G. \& Manrique-Abril F. G., (2008). Condiciones laborales y grado de satisfacción de profesionales de enfermería. Aquichan, 8(2), 243-256.

29. Ismail, W. K. W., Mohamad, N. A. B., Hussain, G., Rashid S. Z. A. \& Rashid, M. A., (2011). Organizational commitment as mediator of charismatic leadership to model subordinates' performance and satisfaction. International Journal of Academic Research, 3(6), 379-385.

30. Juárez-Adauta, S., (2012). Clima organizacional y satisfacción laboral. Rev Med IMSS, 50(3), 307-314.

31. Kim, S., (2004). Individual-level factors and organizational performance in government organizations. Journal of Public Administration Research and Theory, 15(2), 245-261.

32. Leung, K., (1997). Relationships among satisfaction, commitment, and performance: A group-level analysis. Applied Psychology: An International Review, 46(2), 199-205.

33. Leung, M., Chen, D. \& Yu, J., (2008). Demystifying moderate variables of the interrelationships among affective commitment, job performance, and job satisfaction of construction professionals. Journal of Construction Engineering and Management, 143(12), 963-971.

34. Locke, E. A., (1997). The motivation to work: What we know. En M. L. Maehr y P. R. Pintrich (Eds.), Advances in motivation and achievement (Vol. 10, pp. 375-412). Greenwich, CT: JAI Press.

35. López-Araujo, B., Osca, A. \& Peiró, J. M., (2007). El papel modulador de la implicación con el trabajo en la relación entre el estrés y la satisfacción laboral. Psicothema, 19(1), 81-87.

36. López-García, A., Valdez-Martínez, E., Goycochea-Robles, M. V. \& Bedolla, M., (2009). A snapshoot of medical care quality: Health professional and patient satisfaction. Rev Med IMSS, 47(9), 603-610.

37. Mañas, M. A., Salvador, C., Boada, J., González, E. \& Agulló, E., (2007). La satisfacción y el bienestar psicológico como antecedentes del compromiso organizacional. Psicothema, 19(3), 395-400.

38. Martínez, F. J., (2002). El hospital universitario, su naturaleza y sus fines. Medicina Universitaria, 4(16), 187189.

39. Medina, M. L., Medina, M. G. \& Merino, L. A., (2015). La investigación científica como misión académica de los hospitales públicos universitarios. Revista Cubana de Salud Pública, 41(1), 139-146.

40. Meyer, J. P. \& Allen, N. J., (1997). Commitment in the workplace: Theory, research, and application. Newbury Park, CA: Sage.

41. Meyer, J. P., Becker T. E. \& Van Dick, R., (2006). Social identities and commitments at work: toward an integrative model. Journal of Organizational Behavior, 27, 665-683. 
42. Meyer, J. P., Paunonen, S. V., Gellatly, I. R., Goffin, R. D. \& Jackson, D. N., (1989). Organizational commitment and job performance: It's the nature of the commitment that counts. Journal of Applied Psychology, 74(1), 152-156.

43. Molina, J. M., Avalos, F., Valderrama, L. J. \& Uribe, A. F., (2009). Factores relacionados con la satisfacción laboral de enfermería en un hospital médico-quirúrgico. Investigación y Educación en Enfermería, 27(2), 218225.

44. Morris, A. \& Bloom, J. R., (2002). Contextual factors affecting job satisfaction and organizational commitment in community mental health centers undergoing system changes in the financing of care. Mental Health Services Research, 4(2), 71-83.

45. Mowday, R. T., Porter, L. W. \& Steers, R. M., (1982). Employee-organization linkages: The psychology of commitment, absenteeism, and turnover. New York: Academic Press.

46. Mowday, R. T., Steers, R. M. \& Porter, L. W., (1979). The measurement of organizational commitment. Journal of Vocational Behavior, 14, 224-247.

47. Muñiz, J., Peña-Suárez, E., De la Roca, Y., Fonseca-Pedrero, E., Cabal, A. L. \& García-Cueto, E., (2014). Organizational climate in Spanish Public Health Services: Administration and Services Staff. International Journal of Clinical and Health Psychology, 14, 102-110.

48. Nava-Galán, M. G., Hernández-Zavala, M., Hernández-Cantoral, A., Pérez-López, M. T., Hernández-Ramírez, M. G., Matus-Miranda, R. \& Balseiro-Almario, C. L., (2013). Satisfacción laboral del profesional de enfermería en cuatro instituciones de salud. Arch Neurocien (Mex), 18(I), 16-21.

49. Ostroff, C., (1992). The relationship between satisfaction, attitudes, and performance: An organizational level analysis. Journal of Applied Psychology, 77(6), 963-974.

50. Rad, A. M. M. \& De Moraes, A., (2009). Factor affecting employees' job satisfaction in public hospitals: Implications for recruitment and retention. Journal of General Management, 34(4), 51-66.

51. Ringle, C. M., Wende, S. \& Becker, J.-M., (2015). SmartPLS 3 [Software estadístico de ordenador]. Recuperado de http://www.smartpls.com

52. Rositas, J., Alarcón, G. \& Badii, M. H., (2006). El desarrollo y evaluación de la declaración del problema de investigación. Innovaciones de Negocios, 3(2), 331-345.

53. Saldarriaga, J. G., (2014). La concepción del sujeto en la administración: una mirada desde la gestión humana. AGO.USB, 14(1), 223-237.

54. Salgado, E., (2006). Dos textos sobre el desempeño individual en las organizaciones. En Universidad de los Andes - Facultad de Administración, Monografías de Administración: Recursos Humanos. Colombia: Comité de Publicaciones.

55. Salgado, J. F., Remeseiro, C. \& Iglesias, M., (1996). Clima organizacional y satisfacción laboral en una PYME. Psicothema, 8(2), 329-335.

56. Sánchez-Sellero, M. C., Sánchez-Sellero, P., Cruz-González, M. M. \& Sánchez-Sellero, F. J., (2014). Características organizacionales de la satisfacción laboral en España. Revista de Administración de Empresas, 54(5), 537-547.

57. Shore, L. M. \& Martin, H. J., (1989). Job satisfaction and organizational commitment in relation to work performance and turnover intentions. Human Relations, 42(7), 625-638.

58. Susanty, A. \& Miradipta, R., (2013). Employee's job performance: The effect of attitude toward works, organizational commitment, and satisfaction. Jurnal Teknik Industri, 15(1), 13-24.

59. Toro, F., (1998). Predicción del compromiso del personal a partir del análisis del clima organizacional. Revista de Psicología del Trabajo y de las Organizaciones, 14(3), 333-344.

60. Villagómez, M. M., Hernández, A. \& Villarreal, E., (2003). Satisfacción laboral en médicos a seis años de distancia. Rev Med IMSS, 41(5), 399-405.

61. Yáñez, R., Arenas, M. \& Ripoll, M., (2010). El impacto de las relaciones interpersonales en la satisfacción laboral general. LIBERABIT, 16(2), 193-202. 